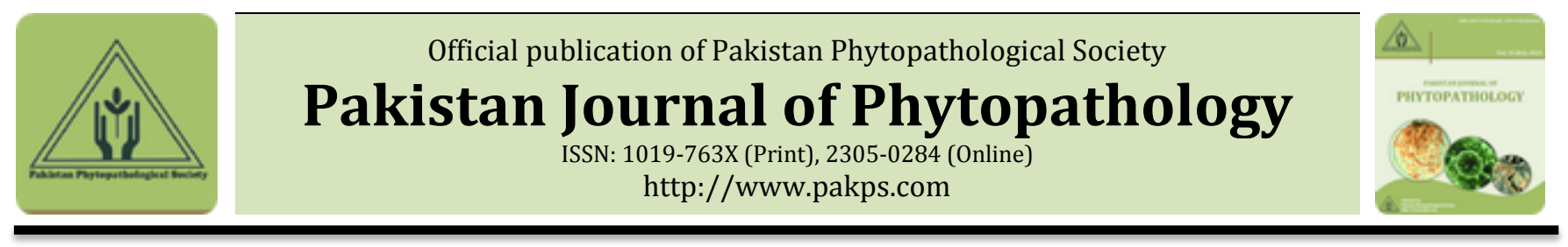

\title{
MANAGEMENT OF SEED BORNE FUNGAL DISEASES OF TOMATO: A REVIEW
}

\author{
aSobia Chohan, aRashida Perveen, aMuhammad Abid, aAtif H. Naqvi, bSafina Naz \\ aDepartment of Plant Pathology, Faculty of Agricultural Sciences and Technology, Bahauddin Zakariya University, \\ Multan, Pakistan. \\ ${ }^{b}$ Department of Horticulture, Faculty of Agricultural Sciences and Technology, Bahauddin Zakariya University, Multan, \\ Pakistan.
}

\section{A B S T R A C T}

Plant diseases caused by different kinds of microorganisms either carried through air, water or present in soil, seeds or propagative planting materials have adverse impact on agriculture production and economy worldwide. Apart from other crops vegetables are also subjected to several seed borne fungal, bacterial and viral pathogens, which cause substantial yield loss upto 10 percent in Pakistan. This article gives vast information regarding significance and prevalence of various kinds of seed borne mycoflora (Alternaria solani, Fusarium oxysporum, F. solani, Botrytis cineria, A. alternata, Chaetomium globosum, Curvularia lunata, Aspergillus niger, Drechslera specifer and Rhizoctonia solani) particularly associated with seeds of tomato. These mycoflora are causative agents of devastating tomato diseases like early blight, fusarium wilt and foot rots, grey mold, root and fruit rots. A range of conventional and modern techniques employed for seed borne fungal detection and different control strategies including chemical and biological methods opted by researchers have been reviewed in present paper. A variety of factors like availability of susceptible plants, favorable environmental conditions and overhead irrigation are serious constraints for plant disease development. Under these conditions, monitoring of plant health and detection of diseases particularly using seed detection assays to screen infested seed lots before planting provide effective disease management strategy.

Keywords: Detection methods, seed borne fungi, seed treatments, tomato.

\section{INTRODUCTION}

Tomato (Lycopersicun esculentum Mill.) also called as "golden apple" belongs to nightshade family Solanaceae is the second extensively grown vegetable crop after potato due to its tangy fruit, taste and high nutritive value throughout the world (Saltueit, 2003). Tomato is high in vitamins particularly vitamin A, C, $\beta$-carotene and essential minerals. A powerful natural antioxidantLycopene is present in red ripe and cooked tomatoes good for both preventing heart diseases and cancer (Madhavi and Salunke, 1998; Olson, 2004).Tomato being short-duration, low price and high economic returns has fetched attraction of growers to produce the crop throughout the year even in places with warmer climates (Naika et al., 2005). Since 1993, tomato production and consumption have almost doubled in the

* Corresponding Author:

Email: sobia_mustafa2006@hotmail.com

(C) 2017 Pak. J. Phytopathol. All rights reserved. world (Van de vooren et al., 1986). Due to its assorted fruits, it is considered as an important cash and industrial crop in many countries including United States, China, Turkey, India and Egypt. According to world's statistics, China is the leading tomato producing country in the world with annual production of about 34 million tones. World production of tomato is estimated at 145 million tones annually over an area of 4.36 million ha, yielding on average basis up to 336 thousand $\mathrm{kg} / \mathrm{ha}$. In Pakistan tomato covers an area of 58.1 thousand hectares with an annual production of about 574 thousand tones (GOP, 2013).

Though, tomato is cultivated worldwide due to its adaptability to wide range of soils and climate (Ahmad, 1976), however, tomatoes are prone to insect pests, abiotic and biotic stresses due to their tenderness as compared to other crops (Ketelaar and Kumar, 2002). Plant diseases are the main limiting factors to total crop losses all over the world and are of growing importance 
as the world population increases. Over 200 diseases caused by various pathogens have been reported on tomato worldwide (Jones et al., 1991). However, seedborne diseases can easily spread from one place to another and serve as an initial source of inoculum potential (Nishikawa et al., 2006). Therefore a high quality seed have significant role in production of sustainable and profitable vegetables. Seed borne diseases are caused by microorganisms including fungi, bacteria, virus and nematodes. Among the parasitic organisms fungi are most frequently encountered on seeds. The infected seeds served as a source of primary infection and establishment of plant diseases (Agarwal, 1981), thus, have adverse effect on seed health, reducing germination ability, poor seedling vigor and transmit fungus to the seedlings, accelerating the deterioration in storage, introducing pathogens into new areas and increasing the inoculum source in the field (Alves et al., 2006).

Fungi being an imperative group of microorganisms are also responsible for tomato seed-borne diseases and cause a substantial yield loss. On tomato, numerous seed-borne fungi viz Fusarium solani, Aspergillus flavus, Rhyzopus stolonifer and Curvularia spp. etc. occur that cause abnormalities to the seeds such as seed toxification, seed rotting, necrosis and seed abortion (Neergard, 1977; Fakir and Khan, 1992). Considering the economic importance of seed-borne fungi and their effect on seed vigor various seed health detection assays are being adopted by seed pathologists to screen and eliminate infested seed lots before planting (ISTA, 1976). Farmers are facing financial constraints with considerable crop losses due to seed-borne mycoflora on their crops. Primary step in any agricultural crop production and protection program is control of seedborne pathogens through various methods. Therefore, substantial control of seed-borne pathogens can be achieved by using single or combination strategies of mechanical, physical, biological and chemical methods.

Prevalence of Seed-borne Mycoflora- A historical Perspective: Seed-borne fungi are microorganisms that may harbor seeds internally causing infection or externally as contaminant (Agarwal and Sincair, 1997), causing pre and post germination death, making them toxic and reduced its quality for consumption as well as for seed industry. Seed-borne mycoflora may be present in the form of hyphae, chlaymydospores, oospores, conidia and sclerotia (Behura et al., 2000;
Bhameapravati, 2006). Tomato being used as a model plant in genetics also prone to numerous seed-borne fungal pathogens. In Pakistan tomato production is enormously reduced due to seed-borne fungi along with other pathogens. An estimation of 10 percent crop losses due to seed borne diseases was reported in Pakistan (Bhatti and Bhutta, 1990). Earlier Ahmad et al; (1993) recorded15 fungi and Perveen and Ghaffar (1995) reported 22 new species belonging to 15 genera of seedborne mycoflora on tomato from Pakistan. Most predominant were: Fusarium solani, F. moniliformae, Alternaria alternata and Drechslera australiensis as predominant fungi. In Bangladesh, similar fungi like Alternaria solani, Fusarium oxysporum, Aspergillus flavus and $A$. fumigatus were also detected on tomato, causing severe damage to seeds (Fakir, 2001). Likewise, Bhatti et al; (2010) recorded Bipolaris spp, Curvularia lunata, F. moniliformae and $F$. semitectum with infection percentage of 1.5, 0.5-7.5, 0.5 and 1-3 respectively from tomato seeds.

Storage period also have great impact on occurrence of different mycoflora. Black lesions on tomato fruit when stored at $30^{\circ} \mathrm{C}$ developed due to seed-borne Cladosporium spp (Shersingh et al., 1983). Total 12 fungi were isolated from fruits and seeds of tomato (Dhekle and Bodke, 2013), all of the fungi were associated to tomato fruits as well, except for Cladosporium sp that showed incidence only on seeds. Ismael, (2010) detected Aspergillus clavatus, A. flavus, A.niger, Penicillium digitatum, Pythium sp., Rhizopus arrhizus and $R$. Stolonifer from tomato seeds of Sulaimania region with frequency percentage rate: $0.42,0.08,0.4,0.04,0.025$, 0.02 , and 0.266 whereas with frequency percent of 0.10 , $0.10,0.87$ and $0.25 \%$ A versicolor, $P$. digitatum, $R$. arrhizus and $R$. stolonifer predominate tomato seeds from Germaine region respectively. As a matter of fact, tomato seeds yielded large number of fungal isolates belonging to Alternaria, Fusarium, Botrytis, Pythium, Drechslera and Rhizoctonia genus causing seed rot, damping off, root and fruit rot, foliar and wilt diseases (Mathur, 1983; Kassim and Monawar, 2000). Whereas, Mogle and Mane (2010), found twelve species associated with treated and untreated seeds of tomato. Nishikawa et al; (2006) while evaluating 109 species of seed-borne fungi from three cultivars of tomato found Hormonema spp., one of the most common genera on tomato seeds from old lots of $\mathrm{cv}$. delicious as compared to new lots, additionally; cluster analysis indicated that tomato seed 
mycoflora is greatly influenced by harvesting year and locality of cultivars.

Depending upon presence of fungi either on seed coat or in the seed, mycoflora are however, isolated both as surface contaminants, internally seed-borne flora and are known to cause serious field diseases. Bankole (1996) isolated 18 fungal species from two tomato varieties, Ibadan and Ife1as externally and internally seed-borne. They found most of the species to be surface contaminants while Alternaria longissima, Aspergillus flavus, A.niger, Curvularia lunata, Fusarium moniliforme, F. oxysporum and Phoma destructive were present internally. Agarwal and Sinclair (1997) also affirmed that seed may either be infected internally or present as surface contamination. Fusarium wilts, one of the most devastating diseases of tomato caused by Fusarium oxysporum f.sp. lycopersici is an internally transmitted fungus (Singh et al., 1980). Sati et al.,(1989) isolated five cladosporium spp from two tomato cultivars. Cladosporium oxysporum and C. cladosporioides were most frequently isolated with incidence of $1-25 \%$ and 1 $10 \%$ respectively. Furthermore, C. cladosporioides induced $33 \%$, C. oxysporum $25 \%$ and C. fulvum $24 \%$ seed and seedling infection in "chaubattia red" variety, whereas, in "shiouse cultivar" caused 39\%, 35\% and $28 \%$ seed and seedling mortality respectively. Similarly earlier workers reported that a total of seventeen fungi were associated with seeds of tomato var. local, among them the predominant fungi were Aspergillus niger, $A$. flavus, Fusarium moniliforme, Rhizopus nigricans, Curvularia lunata and Alternaria alternate (Telang, 2010). According to Nation et al., (2011), twelve fungi were found coupled with seeds of four tomato cultivars in Gujrat, India. Most predominant were Alternaria alternata, Aspergillus flavus and A. niger whilst Aspergillus amstelodami and Cunnnin ghameliaechinulata were new records.

Detection Methods: High quality seed is an important prerequisite for sustainable crop production. Furthermore, asymptomatic infested seeds, low pathogen populations on seeds make testing seed health a difficult task. A range of conventional and modern detection assays exist for different seed fungi, adopted by seed pathologists for detection of seedborne mycoflora. However, few of them satisfy the minimum requirements for adequate seed tests comprises direct examination, blotter test, agar plate method, seedling growing-on test and serological assays. Though, for preliminary detection of fungi these are the common laboratory seed health testing methods, but blotter test is simplest and most widely used method (ISTA, 1976).

Conventional Methods: The magnitude of seed health testing cannot be underestimated. Hence to boost food production and crop yield sowing healthy seed is of our major concern. Depending upon nature of fungi two methods possibly required for detection of a pathogen (Mathur, 1995). As Perveen and Ghaffar (1995), Kassim and Monawar (2000) and Nation et al; (2011) found agar plate method superior over blotter method as it yielded higher number and percentage of seed mycoflora of tomato, eggplant, okra and radish. Whereas, Rashid et al., (2010) evaluated seed health status of tomato seeds through blotter incubation method. Aspergillus spp., Fusarium spp and Penicillium spp were identified from tomato seed samples. Similarly, Natsugah et al., (2004) using blotter plate method, assessed 152 seed samples including sorghum, rice, maize, pearl millet, tomato and watermelon for associated seed-borne fungi. Sultana and Ghaffar (2009) revealed blotter and deep-freezing methods more efficient compared to agar plate method as these methods yielded maximum fungi on bottle gourd seeds both quantitatively and qualitatively. Asha et al.,(2011) with blotter test isolated Fusarium oxysporum from infected seeds of PKM-I tomato cultivar which showed $7 \%$ incidence. Despite the fact that some researchers revealed seed mycoflora through agar plate method, however due to high competition of dominant fungi for nutrition on agar plates, the blotter method isolated higher numbers of fungi than agar method.

Modern Techniques: Besides, pathogenic strains seed mycoflora also include fast growing saprophytes that may overgrow, making isolation of fungal pathogen complicated. Further, some races of pathogenic fungi are morphologically identical. Consequently, use of modern techniques like immunoassays and nucleic acid-based techniques can aid in perceptive detection of seed mycoflora. Serological based seed assays like ELISA are effectively in use for detection of higher percentage of fungi and bacteria compared to agar plate procedure which is time consuming (Afouda et al., 2009). Moreover, Alves and Edson (2012) suggested that adoption of scanning electron microscopy (SEM) methodology in blotter test analysis could be useful to identify fungal structures and finally supportive in seed 
certification programs as well as to facilitate conduction of more detailed taxonomic classification of seed-borne fungi.

The application of nucleic-acid based detection methods in seed health testing has been facilitated by integrating conventional or real-time PCR with other technologies like BIO-PCR, IMS-PCR etc. Since many PCR-based detection methods have been developed and applied to seed-borne pathogens. Munkvold (2009) reviewed research innovations in seed-borne pathogens detection, use of seed treatments and advancement towards standardization of seed health testing methods. Up till 2005 at least 100 pathogens had been detected with PCR- based seed health tests (Guillemete et al., 2004) hence, acquired more specific detection of Verticillium sp. in tomato with real-time PCR assay. However, in the developing world, obstacles like capital costs and technical expertise for establishing PCR capabilities can be challenging in the implementation of PCR-based methods for seed health testing. Subsequently more work is needed to check the role of various detection methods in seed health testing programs.

Effect on Germination: As a result of fungal infection large number of toxins in seeds are produced which may affect seed metabolism at cellular level. These mycotoxins greatly affect seed germination and seedling vigor. Aflatoxins produced by Aspergillus flavus disturb the metabolism by inhibiting chlorophyll and various enzymes synthesis consequently reducing seedling growth (Mathur and Jorgensen, 1988). Isolates of $A$. alternata, Penicillium waksmanii, and Arthrinium $s p$ detected on tomato seeds significantly inhibited influential root elongation ultimately causing seedling rot three days after germination (Nishikawa et al., 2006). Fungal exudates produced by seed mycoflora Aspergillus niger, A. clavatus and Sclerotinia sp significantly decreased the percent germination rate of tomato and pepper seeds (Ismael., 1997; 2000; 2010). Similarly, Telang (2010) also found seed-borne fungi on tomato var. local to be inhibitory for seed germination and caused severe loss in seedling vigor.

Seed Treatments: Seed health is an important step in crop disease management. Due to changing global climate, emergence of diseases in endemic form turns out to be a challenge in safeguarding plant health. Hence, judicious and accurate diagnoses of problem and pathogen surveillance allow time for application of mitigation strategies. Epiphytotic plant diseases have shown to be prevented by treatment of seeds to kill the pathogens carried within or on the seed. Compared to air-borne or soil borne fungi, however, seed-borne fungi are easily controlled. A wide range of chemical, biological physical, and mechanical approaches have been used to reduce pathogens from seeds both internally and externally, and to help protect seeds from soil-borne pathogens (McGee, 1995; Maude, 1996; Neergard, 1977).

Through Chemicals: Seed-borne pathogens results in mycotoxic problems to human health, hence seeds should be treated with suitable fungicides before sowing. Traditionally, seed treatment through fungicides via spraying, soil drenching and dusting has historical importance (Orereke et al., 2007), also protecting seeds and seedlings from the common soil-inhabiting fungi that cause seed rots and damping-off diseases. Kassim and Monawar (2000) treated (in vitro) five vegetable seeds including tomato, eggplant, okra etc in Gazan province with $0.2 \%$ fungicides viz., Benomyl, Cozib and Mancozeb before incubation. All tested fungicides showed inhibitory effect on most of the isolated fungi. However, benomyl was the most effective against all fungi detected on tomato seeds. Amini et al., (2010) evaluated six fungicides against Fusarium wilt causing fungi of tomato in vitro and in vivo. Prochloraz and bromuconazole followed by benomyl and carbendazim found most effective against Fusarium oxysporum $\mathrm{f} \mathrm{sp}$. lycopersici when applied to seedlings at recommended doses. Additionally, no phytotoxic effects observed on seedlings.

Through Bio-agents: Certainly, chemical fungicides show profound results on seed-borne fungal diseases but on the other hand adversely influence beneficial microorganisms present in the soils and environment. Besides, indiscriminate use of fungicides not only hazardous to animals and human beings but also develops resistance among target pathogen. Since, the fungicides affect the non-target organisms as well (Banerjee et al., 2005), researchers are moving towards use of more ecofriendly and cheap alternative methods of treating seeds like acid treatments, antagonistic microbes and plant extracts to control diseases. These are promising alternatives that release plant growth regulators which influence the overall crop growth and improve the morphological characteristics. 
In this respect, Kasselaki et al., (2008) tested nitrite solution and resistance inducers in a growth chamber against Didymella lycopersici- a seed-borne fungus of tomato. Ten minutes seed soaking with nitrite solution at $300 \mathrm{mM}$ concentration and resistance inducer Tillecur (mustard seed extract) at $0.05 \mathrm{~g} / \mathrm{ml}$ reduced seed germination losses and disease incidence in germinating seedlings. Mogle and Mane (2010) evaluated biofertilizers and benomyl fungicide on seed germination and mycoflora of tomato. Seeds treated with Azotobacter and Trichoderma comparatively showed highest seed germination (96\%) followed by Trichoderma and Rhizobium mixture (95\%) while minimum (78\%) was recorded with Benomyl. Additionally, seed dressing with biofertilizers greatly reduced the incidence of Alternaria alternata, Rhizoctonia solani and Pythium aphanidermatum whereas; Fusarium oxysporum was completely inhibited over control. Effect of various strains of Trichoderma virens studied on pathogen growth, seed germination and vigor of tomato seeds. In India, local isolate $T v_{1}$ among tested isolates increased the plant growth and inhibited mycelia growth of $F$. oxysporum f. sp. lycopersici under in vitro condition. While seed treatment plus soil application of talc based formulation of $T v_{1}$ also significantly reduced disease incidence (54.66\%), compared to other isolates of $T$. virens under green house conditions (Christopher et al., 2010).

Likewise, Asha et al., (2011) examined biocontrol potential of Pseudomonas fluorescens, isolated from rhizospheres of tomato fields against seed and soil borne Fusarium oxysporum $f$ sp. lycopersici. Though, all the ten isolates of $P$. fluorescens inhibited mycelial growth of $F$. oxysporum to various extents, but maximum inhibition zone $(2.2 \mathrm{~cm}$ diameter) was measured for Pf2 isolate and minimum zone $(0.2 \mathrm{~cm}$ diameter $)$ was found for Pf8 isolate. Moreover, P. fluorescens increased the seed germination (up to $89 \%$ ) and also enhanced seedling vigor of tomato.

Through Botanicals: Plants are the richest source of organic chemicals and produce wide variety of ecofriendly secondary metabolites (Okigbo and Nmeka, 2005; Okigbo and Omodemiro 2006; Jamil et al., 2007; Riaz et al., 2010). Instead of chemical fungicides use of botanicals is one of the recent approaches for controlling seed-borne and other plant diseases (Howlader, 2003; Islam et al., 2006). Antifungal activity of various plant extracts viz: garlic clove, neem leaf, allamonda leaf, ginger rhizome, kalijira seed, bel leaf, turmeric rhizome, katamehedi leaf and onion bulb were evaluated against seed-borne damping-off of tomato. Seed treatment with plant extracts showed varied degree of performance towards percent damping-off of tomato. However, the highest seed germination $(86.67 \%)$ and minimum incidence of damping-off of tomato was recorded with neem leaf extract followed by garlic clove and allamonda leaf extract (Islam and Faruq, 2012). Rashid et al., (2010) treated tomato seeds with garlic tablets at different concentrations against seed-borne fungal diseases. Prevalence of fungal pathogens and increasing seed germination $(71.25 \%)$ was recorded even at $1: 3 \mathrm{w} / \mathrm{v}$ dose. Moreover, in pot experiment garlic tablets at same concentration $(1: 3 \mathrm{w} / \mathrm{v})$ showed best performance with seedlings having highest germination and reduced blighted, damping off symptoms. Seed-borne fungal diseases were reduced when faba bean, tomato and lettuce grown under soils of Artemisia afra shrub. This might be due to presence of biologically active compounds in the soils/roots which may have inhibitory effect on seed germination of faba bean, tomato, peas and lettuce (Materechera and Mbokodi, 1997). Similarly, Ritz (2008) observed the effect of Calatropis procera residues alone and in combination with Fusarium oxysporum inoculum on tomato cultivars flora-dade, castle rock and strain B. Percent emergence, root and shoot length of tomato cultivars were reduced in the presence of $F$. oxysporum but improved with combination of plant residues and tomato pathogen by suppressing the pathogenic fungus.

\section{CONCLUSIONS}

Tomato being a highly nutritive vegetable crop is cultivated throughout the world and placed after potato due to its large consumption. But seed-borne pathogens of tomato are of serious concern in seed production industry as they adversely influence the germination and vigor of the seedlings, and consequently yield and quality of the product deteriorate greatly. Therefore, use of healthy seed and sound seed certification program is a key factor to increase its production. Seed treatments are essential in controlling seed-borne diseases, therefore, integrated approach is recommended to minimize the incidence of diseases carried through seeds of various crops including tomato. 


\section{REFERENCES}

Afouda, L., G. Wolf and K. Wydra. 2009. Development of a sensitive serological method for specific detection of latent infection of Macrophomina phaseolina in cowpea. J. Phytopathol. 157:15-23.

Agarwal, V. K. and J. B. Sinclaire. 1997. Principles of Seed Pathology, $2^{\text {nd }}$ ed. CRC Press, Inc. Boca Raton, New York, London, Tokyo, :539 pp.

Agarwal, V. K. 1981. Seed-borne Fungi and Viruses of some important crops, Walnitali, University Press, Pantangar. : $137 \mathrm{pp}$.

Agarwal, V. K. and O.V. Singh. 1974. Seed-borne fungi of jute and their control. Ind. Phytopathol. 27: 651652.

Ahmad, I., S. Iftikhar and A. R. Bhutta. 1993. Seed-Borne Microorganism in Pakistan. Pakistan Agriculture Research Council, Islamabad. 32pp.

Ahmad, K. U. 1976. PhulPhal, O. Shak, Sabji. $3^{\text {rd }}$ Edn. Alhaz Kamisuddin Ahmad. Banglow No. 2 Farm Gate, Dhaka-15, Bangladesh 470pp.

Amini, Jahanshir, Sidovich and Dzhalilov. 2010. The effects of fungicides on Fusarium oxysporum f. sp. lycopersici associated with Fusarium wilt of tomato. J. of Pl. Protect. Res. 50(2): 172-178.

Alves, M. C., E. A. Pozza, J. C. Machado, D. V. Araújo, V. Talamini, M. S. Oliveira. 2012. Geostatistics as methodology to study the space-time dynamics of diseases transmitted by seed-borne Colletotrichum spp. Fitopatologia Brasileira. 31: 557-563.

Asha B. B., N. S. Chandra, S. A. C. Udaya, C. Srinivas, S. R. Niranjana. 2011. Biological control of $F$. oxysporum f. sp. lycopersici causing wilt of tomato by Pseudomonas fluorescens. Intr. J. Microbiol. Res. 3(2): 79-84.

Behura, C., P. Ray, C. C. Rath, R. K. Mishra, O.S. Ramchandraiah, J. K. Charyulu. 2000. Antifungal activity of essential oils of curcuma longa against five rice pathogens in vitro. J. Essential oil bearing plants. 3(2): 79-84.

Bhamaeapravati, S., S. Juthajpruth, W. Mahachai and G. Mahady. 2006. Antimicrobial activity Boesenbergiaroutunda(L.) Mans f. Mlyristica fragrans Houtt.Against helicobacter pylori. Sonklankarin. J. Sci. Technol. 28(1): 157-163.

Bhatti, M. A. R. and Bhutta, A. R. 1990. Strengthening Teaching, Training and Research in Seed Pathology in Pakistan (P-4-15)Publ. in Seed Pathology in Pakistan (Edited by Ahmad and Bhutta, 1990) FSC\&RD, GOP, Islamabad.

Banerjee, M. R., L. Yesmin and J. K. Vessey. 2005. Plant growth promoting rhizobacteria as biofertilizers and biopesticides. Handbook of microbial biofertilizer. Food Products Press, an imprint of The Haworth Press, Inc., 10 Alice Street, Binghamton, NY 13904-1580.
Bankole, S. A. 1996. The distribution and pathogenicity of the seed mycoflora of two tomato varieties cultivated in western Nigeria. Afr. Crop Sci. J. 4( 4): 491-496.

Bhatti, F. J., H. Ghazal, G. Irshad, N. Begum, A. R. Bhutta. 2010. Study on seed-borne fungi of vegetable seeds. Pak. J. Seed technol. 2(15): 99-106.

Dhekle, N. M. and S. S. Bodke. 2013. Studies on fungal diversity associated with cauliflower, tomato and bhendi. Rev.Res. J. 2(6):1-7

Fakir, G. A. 2001. An annotated list of seed-borne disease in Bangladesh. Seed Pathology Laboratory. Department of Plant Pathology, BAU, Mymensingh. $41 \mathrm{p}$.

Fakir, G. A. and A. A. Khan. 1992. Control of some selected seed-borne fungal pathogens of jute by seed treatment with garlic extract. Proc. BAU Res. Prog., 6: 176-180.

Gary, P. M. 2009. Seed Pathology Progress in Academia and Industry. Ann. Rev. Phytopathol. 47: 285-311.

GOP. 2012-13. Agricultural Statistics of Pakistan. Statistics Division, Govt. Pakistan, Islamabad.

Guillemete, T., B. Iacomi-Vasilescu and M.V. Usa. 2004. Conventional and real-time PCR-based assay for detecting pathogenic Alternaria brassicae in cruciferous seed. Plant Dis. 88: 490-496.

Habib A., S. T. Sahi, M. U. Ghazanfer and A. Safdar. 2007. Evaluation of some fungicide against seed mycoflora of Eggplant and their comparative efficiency regarding seed germination. Intr. J. Bio. 9(3): 519-520.

Howlader, A. N. 2003. Effect of seed selection and seed treatment on the development of phomopsis blight and fruit rot of egg plant. MS thesis, Bangladesh Agricultural University, Mymensingh, Bangladesh.

Islam M. T. and A. N. Faruq. 2012. Effect of some medicinal plant extracts on Damping-off disease of winter vegetable. World Appl. Sci. J. 17 (11): 14981503.

Islam, M. A., F. M. Aminuzzaman, M. R. Islam and M. S. Zamal. 2006. Seed treatment with plant extract andVitavax-200 in controlling leaf spot (Bipolaris sorokiniana) with increasing grain yield of wheat. Intr. J. Sust. Agric. Technol. 2(8): 15-20

Ismael, J. H. S. 2010. Isolation and identification of some fungi from certain solanaceous seeds in Sulaimania and Germian regions and their exudates effects on germination rate. Agric. Bio. J. N. America.1 (4): 615-619.

Ismael, J. H. S. 2000. Isolation and identification of some pathogenic fungi from rice seeds. Kurdistan Academician Journal (KAJ ).1A(1):17-21 .

Ismael, J. H. S. 1997. The effect of some isolated fungi from some wheat cultivars and their exudates on 
seed germination rate in Sulaimani Province. Zankoy Sulaimany Journal. 1(1):87-95.(In Arabic)

ISTA-International Seed Testing Association. 1976, "International rules for seed testing", Seed Science Technology. 13: 299-335.

Jamil, A. M. S., M. M. Khan and M. Ashraf. 2007. Screening of some medicinal plants for isolation of antifungal proteins and peptides. Pak. J. Bot. 39:211-221.

Jones, J. B., J. P. Jones, R. E. Stall and T. A. Zitter. 1991. Compendium of tomato diseases.AP, Minisota.US.

Junji, N. T. Kobayashi, K. S. T. Chibana, K.T. Natsuaki. 2006. Seed-borne fungi detected on stored solanaceous berry seeds and their biological activities. J. Gen. Pl. Pathol. 72:305-313.

Kasselaki, A. M., N. E. Malathrakis, D. E. Goumas, J. M. Cooper, \& C. Leifert. 2008. Effect of alternative treatments on seed-borne Didymella lycopersici in tomato. J. of Appl. Microbio. 105(1): 36-41.

Kassim-Al M. Y. and M. N. Monawar. 2000. Seed-borne fungi of some vegetable seeds in Gazan province and their chemical control. Saudi J. Biol. Sci. 7(2): 179-184.

Ketelaar, J. W. and P. Kumar. 2002. Vegetable Integrated Production and Pest Management: The Case for Farmers as IPM Experts. International Conference on Vegetables; ITC Hotel Windsor Sheraton and Towers, Bangalore, India. 1-14.

Madhavi, D. L. and D. K. Salunkhe. 1998. Handbook of Vegetable Science and Technology. D.K Salunkhe and S.S. Kadam [eds]. Marcel Dekker, New York,171-201pp.

Marcelo de, C. A. and E. A. Pozza. 2012. Scanning electron microscopy detection of seed-borne fungi in blotter test. Current Microscopy Contributions to Advances in Science and Technology (A. MéndezVilas, Ed.): 230-238.

Mogle, U. P. \& R. Y. Mane. 2010. Antagonistic effect of biofertilizers against seed born mycoflora of tomato (Lycopersicum esculentum). Res. J. Agric. Sci. 1: 255-258.

Munkvold G. P. 2009. Seed pathology progress in academia and industry. Ann. review of phytopathol. 47: 285.

Materechera, S. A. and P. M. Mbokodi. 1997. Emergence of crop seedlings in soils associated with bare patches beneath the canopy of the aromatic shrub Artemisia afra. Appl. Pl. Sci. 11: 35-38.

Mathur, S. B. and O. Kongsdal. 2003.Common Laboratory Seed Health Testing Methods for Detecting Fungi. Kandrup Bogtrykkeri, Arhusgade 88, DK - 2100 Copenhagen, Denmark.

Mathur, S. B. 1995. Some Aspect of Seed Pathology that deserve immediate attention. Ind. J. Mycol. Pl. Pathol.25 (1\&2): 13-24.
Mathur, S. B. and J. Jorgensen. 1988. Proceeding of the CTA Seminar held at Copenhagen, Denmark, 20-25 June, 1988.

Mathur, S. B. 1983.Testing seeds of tropical species for seed-borne diseases. Seed Science and Technology.ll: 113-l28.

Maude, R. B. 1996. Seed-borne diseases and their control. Cambridge: CAB International, 280p.

McGee, D. C. 1995. Epidemological approach to disease management through seed technology. Ann Rev. Phytopathol. 33: 445-466.

Naika, S., J. V. L. de Jeude, M. de Goffau, M. Hilmi and B.van Dam. 2005. Cultivation of tomato. $4^{\text {th }}$ ed. (Digigrafi publishing, Wageningen,Netherlands: Agromisa).ISBN Agromisa: 90-8573-039-2.

Narain, A. and C. Panigrah. 1971. Efficiency of some fungicidal compounds to control Colletotrichum capsici in vitro and in vivo. Indian Phytopathol. 24:593-596.

Natsugah, S. K., L. Vibeke, I. D. K. Atokple and S. K. Ayensu. 2004. Seed-borne mycoflora of major food crops in Ghana. J. Sci. Tech. 24(2): 22-31.

Nation, N., G. C. Jadeja and S. T. Patel. 2011. Seed mycoflora of tomato (Lycopersicon Esculentum Mill.) cultivars collected from different locations of Gujarat. J. Plant Dis. Sci. 6(2): 145-149.

Neergaard, P. 1977. Seed Pathology. The Macmillan Press Ltd. London. pp 11 - 87.

Nishikawa, N., T. Kobayashi, K. Shirata, T. Chibana, K. S. T. Chibana and K. T. Natsuaki. 2006. Seedborne fungi detected on stored solanaceous berry seeds and their biological activities. J. Gen. Plant. Path. 72: 305-313.

Okigbo, R. N., and I. A. Nmeka. 2005. Control of yam tuber rot with leaf extracts of Xylopia aethiopia and Zingiber officinale. Afri. J. Biotech. 4: 804-807.

Okigbo, R. N., and O. D. Omodemiro. 2006. Antimicrobial effect of leaf extract of pigeon pea (Cajanus cajan (L.) Mill sp) on some human pathogens. J. Herbs, spices and Med Plants. 12: 117-127.

Okereke V. C., R. C. Wokochaand M. I. Godwin-Egein. 2007. Evaluation of Trichoderma hazarium some botanicals and a fungicide on Sclerotium wilt of potted Tomato. Agriculture Journal. 2(4): 453-456.

Olson, M. E. 2004. Combining Data from DNA Sequences and Morphology for a Phylogeny 696 of Moringaceae (Brassicales). Syst. Bot. 27, 55-73.

Perveen, S., and A. Ghaffar. 1995. Seed-bornemycoflora of tomato. Pak. J. Bot. 27(1): 201-208.

Riaz, T., S. N. Khan and A. Javaid. 2010. Management of corm-rot disease of gladiolus by plant extracts. Nat. Prod. Res. 24: 1131-1138.

Ritz. M. A. 2008. Phytotoxic effect of Calotropis Procera extract on seedling development and rhizosphere mycoflora of tomato plants grown in soil infested with Fusarium oxysporum f.sp. lycopersici. World App. Sci. J. 3(3): 391-397. 
Saltueit, M. E. 2003. Mature Fruit Vegetables. In: Postharvest Physiology and Pathology of Vegetables (eds. J. A bartc and J. K. Brecht) Marcel Dekker, New York. 332.

Sati, M. C., A. P. Dhayani and R. D. Khulbe. 1989. Distribution and seed- plant transmission of Cladosporium spp. in red pepper, bell pepper and tomato crops of Kumaun Himalya, UP, India. Proceedings in Indian National Science Academy. 55(4): 291-294.

Shersingh, D. P. Thakur and J. P. Singh. 1983. Post harvest decay of ripe tomato fruits caused by Cladosporium oxysporum. Indian phytopathol. 36: 723 - 724.

Singh, U., H. B. Singh and R. B. Singh. 1980. The fungicidal effect of neem (Azadirachta indica). Extracts on some soil-borne pathogens of grain (Cicer arietimium) Mycol. 72: 1077 - 1093.

Sultana, N. and A. Ghaffar. 2009. Seed-borne fungi associated with bottle gourd (lagenaria siceraria(mol.) Standl. Pak. J. Bot. 41(1): 435442.

Telang, S. M. 2010. Effect of extracts of various plant parts on seed mycoflora and seed germination of tomato. Asian Sci. Hind Institute of Science and Technology. 5(1): 15-18.

Van de vooren, J., G. W. H. Welles and G. Hayman. 1986. Glasshouse crop production. In: The Tomato Crop: A Scientific Basis for Improvement (Eds. Atherton, J. G. and Rudich, J.), Chapman and Hall Ltd, London:443-484. 